\title{
Numerical Study on NOx Emissions of Methane Re-Combustion in a 600 MWe Coal-Fired Boiler
}

\author{
Xiaotao Zhang, Hussain Ahmad Madni Gondal, Foyuan Duan, Weidong Zhang, Haoliang Mu, \\ Chengyu Zhang, Aijun Wang*
}

Departments of Electric Power, North China University of Water Resources and Electric Power, Zhengzhou, China

Email: *wangaijun@ncwu.edu.cn

How to cite this paper: Zhang, X.T., Gondal, H.A.M., Duan, F.Y., Zhang, W.D., $\mathrm{Mu}$, H.L., Zhang, C.Y. and Wang, A.J. (2020) Numerical Study on NOx Emissions of Methane Re-Combustion in a $600 \mathrm{MWe}$ Coal-Fired Boiler. Energy and Power Engineering, 12, 101-107.

https://doi.org/10.4236/epe.2020.123008

Received: February 29, 2020

Accepted: March 24, 2020

Published: March 27, 2020

Copyright $\odot 2020$ by author(s) and Scientific Research Publishing Inc. This work is licensed under the Creative Commons Attribution International License (CC BY 4.0).

http://creativecommons.org/licenses/by/4.0/

\begin{abstract}
The fuel staging combustion technology is a promising low NOx combustion technology for coal-fired boiler. In order to reduce NOx emissions, the burners of a $600 \mathrm{MWe}$ coal-fired boiler are retrofitted in which methane gas is selected as a secondary fuel for re-combustion. The CFD models of combustion process are built to investigate effects of the methane gasratio on combustion process and NOx emissions. A total of 4 cases are numerically studied, including the pure coal combustion case, the coal combustion with $7.5 \%, 10 \%$, $12.5 \%$ of methane gas re-combustion cases respectively. The results show that the re-combustion of methane can reduce the temperature at primary combustion zone, but increase the temperatures at the re-combustion area and the furnace outlet. The NOx concentration at the furnace outlet reduces with the increasing methane gas ratio. Methane re-combustion can greatly benefit to the NOx emissions reduction.
\end{abstract}

\section{Keywords}

Numerical Simulation, Re-Combustion, NOx Emission Reduction

\section{Introduction}

The past many years have seen the emergence of a growing desire worldwide to take actions to protect the environment from the degrading effects of all forms of pollution. The gaseous pollutant NOx is a primary air pollution composition from the combustion of coal for power generation. A broad range of NOx control technologies have been employed [1]. The low NOx combustion and the flue gas de-nitrification technologies are the main methods to reduce nitrogen oxide emissions from coal-fired boilers. The fuel staging combustion technology is a promising technology at present [2]. The fuel staging combustion, also known as 
re-combustion, has been widely concerned by scholars. This technology reduces NOx emissions by setting up a less oxygen-burning section in furnace to restore a part of NOx to $\mathrm{N}_{2}$ [3] [4]. There are several kinds of material that can be used as re-combustion fuel, such as ultra-fined coal, biomass raw materials and some combustible gases [5]. Gaseous fuels are the first choice for re-combustion because they are easier to be fully mixed and burnt out [6]. Zhang and others carried out the research of a biomass gasification gasifier coupled to a $330 \mathrm{MW}$ coal-fired boiler, it was found that biomass gas has little impact on the normal boiler operation and can effectively reduce the emissions of $\mathrm{NOx}, \mathrm{SO}_{2}$ and other pollutants [7]. Glarborg et al. also carried out a study on the re-combustion characteristics of biomass gas, the results showed that, a higher methane concentration can lead to the greater NOx reduction rate at the excess air coefficient of 0.9 in re-combustion zone [8]. Shi et al. studied the effect of methane on the mixing characteristics of gas re-combustion in a coal-fired boiler [9]. Wu et al. studied the effect of biomass volatiles $\left(\mathrm{CH}_{4}, \mathrm{CO}, \mathrm{H}_{2}\right.$ and $\left.\mathrm{CO}_{2}\right)$ on $\mathrm{NO}$ reduction of re-combustion de-nitrification technology. The results showed that the main positive factors of $\mathrm{NO}$ reduction are $\mathrm{CH}_{4}$ and $\mathrm{H}_{2}$ [10]. Su et al. performed the methane re-combustion de-nitrification test at four different levels of metamorphic coal species, the results showed that methane's stay time in re-combustion area is at 0.7 - 0.9 s range, and the re-combustion de-nitrification efficiency is more than $50 \%$ [11]. Lu et al. indicated that the excessive air coefficient, the ammonia nitrogen ratio and other parameters at the re-combustion area have a great impact on de-nitrification efficiency [12]. Many early boilers had no re-combustion zone, causing high NOx emission. In this work, the re-combustion nozzles are added in the burner system to retrofit a $600 \mathrm{MW}$ coal-fired boiler and methane is selected as the secondary fuel. The main objective is to investigate the influences of the methane co-firing ratio on boiler combustion characteristics and NOx emission. The results can provide a theoretical basis for retrofitting old units in service aiming NOx emission reduction.

\section{Boiler Characteristics}

\subsection{Research Objects and Burner Renovation Program}

A 600 MWe super-supercritical boiler is taken as the research object. This is a single furnace tangential firing boiler with a body of $63.55 \mathrm{~m}$ high, $18.816 \mathrm{~m}$ wide and $17.696 \mathrm{~m}$ deep.

As shown in Figure 1, the burner system before transformation is equipped with a total of 15-layer nozzles from bottom to top, including 6 layers of primary air nozzles (i.e., A, B, C, D, E and F), 7 layers of secondary air nozzles (i.e., AA, $\mathrm{AB}, \mathrm{BC}, \mathrm{CD}, \mathrm{DE}, \mathrm{EF}$ and $\mathrm{FG}$ ), and 2 layers of separated over fire air nozzles (i.e., SOFA1 and SOFA2). The burner system is retrofitted by adding a layer of methane gas nozzles (i.e. $\mathrm{G}$ ) and a layer of re-combustion air nozzles (i.e. $\mathrm{GH}$ ). The combustion area of the furnace is divided into the primary combustion zone, the re-combustion zone and the burn-out zone after retrofit of burner system. 


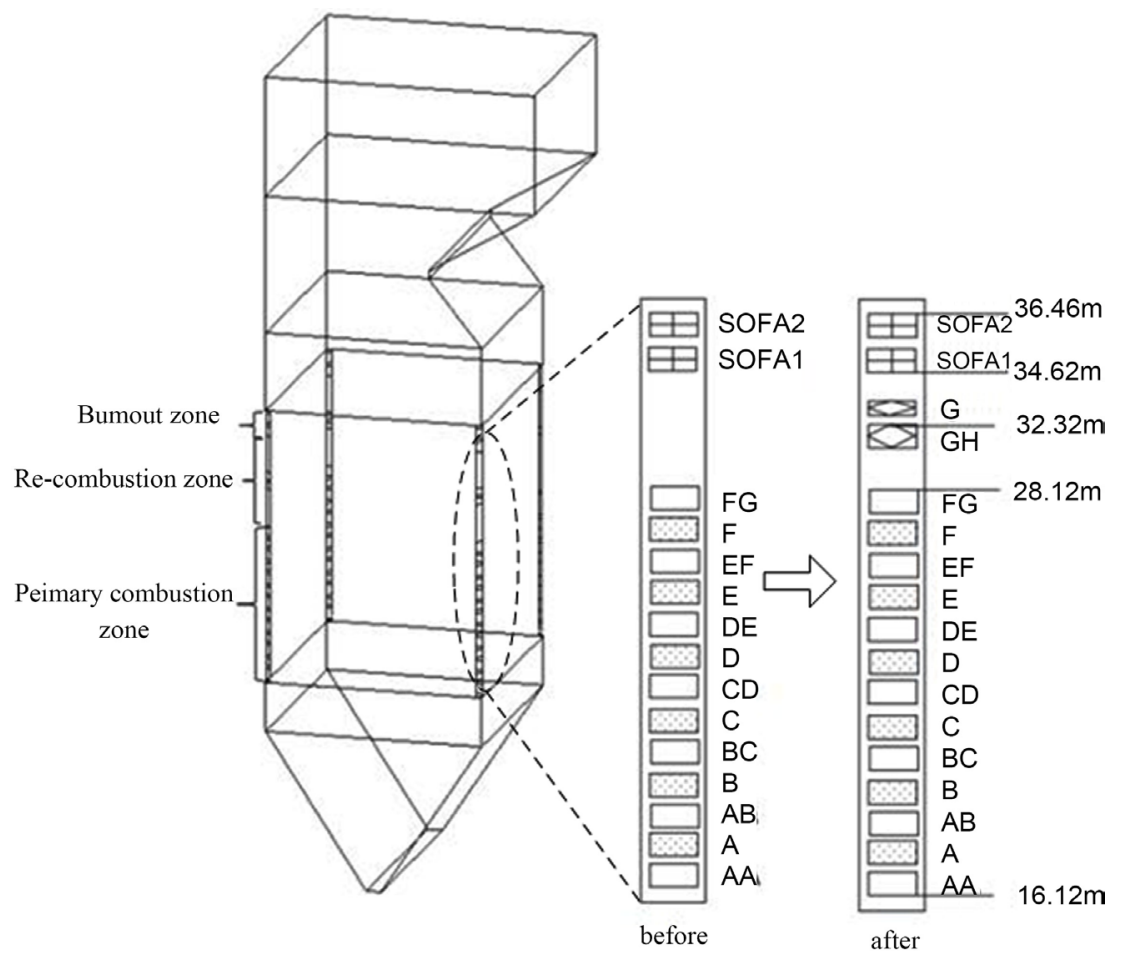

Figure 1. Boiler structure and burner layout before and after transformation.

\subsection{NOx Emissions Reduction Mechanism}

NOx generated in the furnace is divided into thermal type, fuel type and fast type. Its concentration is related to fuel characteristics and combustion conditions. NOx generated from coal combustion is due to high temperature at the primary combustion zone. As the re-combustion fuel is injected into furnace, a fuel-rich reductive atmosphere is formed. A part of NOx generated at the main combustion zone produces a reduction reaction in this area, being transformed to $\mathrm{N}_{2}$, hence the NOx emission is reduced.

The Methane as re-combustion fuel is broken down and produces a large amount of hydrocarbon root CHi to enhance the ability of reducing NOx. Therefore, it is considered one of most ideal re-combustion fuels.

\subsection{Input Parameters}

In order to study the effect of methane re-combustion ratio on combustion process and NOx emissions in furnace, four cases are considered. The total heat input to the boiler is constant. The basic case is coal combustion without re-combustion; the other three cases are the coal combustion with $7.5 \%, 10 \%$ and $12.5 \%$ methane re-combustion ratio (according to heat input) respectively. The input parameters at 4 cases are shown in Table 1 .

\section{Results and Discussions}

\subsection{The Temperature Distribution}

The mean temperature distributions at horizontal cross-section in the furnace 
under different operating conditions are shown in Figure 2. The mean temperature gradually increases with furnace height and reaches its peak at the height of $24 \mathrm{~m}$, and then it gradually decreases. With the increase of re-combustion ratio, the temperature at main combustion zone decreases, but increases at re-combustion zone. The peak temperature at case 1 is around $1900 \mathrm{~K}, 51-72 \mathrm{~K}$ higher than that of case $2-4$. Temperature at the furnace outlet of case 1 is about $1300 \mathrm{~K}, 10-36 \mathrm{~K}$ less than that of case $2-4$. This actually revealed the combustion condition and was related to flue gas concentration.

\subsection{The Flue Gas Component Field Distribution}

In this study, the main components in the flue gas are $\mathrm{O}_{2}, \mathrm{CO}, \mathrm{CO}_{2}$ and $\mathrm{NO}$. The volume fractions of $\mathrm{O}_{2}, \mathrm{CO}, \mathrm{CO}_{2}$ and $\mathrm{NOx}$ mass concentration at each furnace horizontal cross-section under different operating conditions are shown in Figure 3.

As seen from Figure 3, the changing trend of $\mathrm{O}_{2}$ volume fraction is similar at different cases. The $\mathrm{O}_{2}$ volume fraction of case 1 at the primary combustion zone

Table 1. Input parameters under different operating conditions.

\begin{tabular}{|c|c|c|c|c|}
\hline case & 1 & 2 & 3 & 4 \\
\hline $\mathrm{CH}_{4} \mathrm{Re}$-combustion ratio $(\gamma / \%)$ & 0 & 7.5 & 10 & 12.5 \\
\hline Coal mass flow $\left(\mathrm{B}_{0} / \mathrm{kg} \cdot \mathrm{s}^{-1}\right)$ & 3.09 & 2.86 & 2.78 & 2.70 \\
\hline Primary air speed $\left(\mathrm{v}_{1} / \mathrm{m} \cdot \mathrm{s}^{-1}\right)$ & 25.45 & 25.13 & 25.04 & 24.94 \\
\hline Secondary air speed $\left(\mathrm{v}_{2} / \mathrm{m} \cdot \mathrm{s}^{-1}\right)$ & 57.67 & 48.67 & 47.09 & 45.50 \\
\hline Separated over fire air speed $\left(\mathrm{v}_{\mathrm{SOFA}} / \mathrm{m} \cdot \mathrm{s}^{-1}\right)$ & 50.91 & 50.32 & 50.12 & 49.93 \\
\hline Re-combustion methane speed $\left(\mathrm{v}_{\mathrm{CH}} / \mathrm{m} \cdot \mathrm{s}^{-1}\right)$ & 0 & 27.90 & 37.20 & 46.50 \\
\hline $\mathrm{CH}_{4}$ volume flow $\left(\mathrm{V}_{\mathrm{CH} 4} / \mathrm{m}^{3} \cdot \mathrm{s}^{-1}\right)$ & 0 & 2.86 & 3.82 & 4.77 \\
\hline Re-combustion air speed $\left(\mathrm{v}_{\mathrm{r}-\mathrm{c}, \text { air }} / \mathrm{m} \cdot \mathrm{s}^{-1}\right)$ & 0 & 31.35 & 41.80 & 52.25 \\
\hline
\end{tabular}

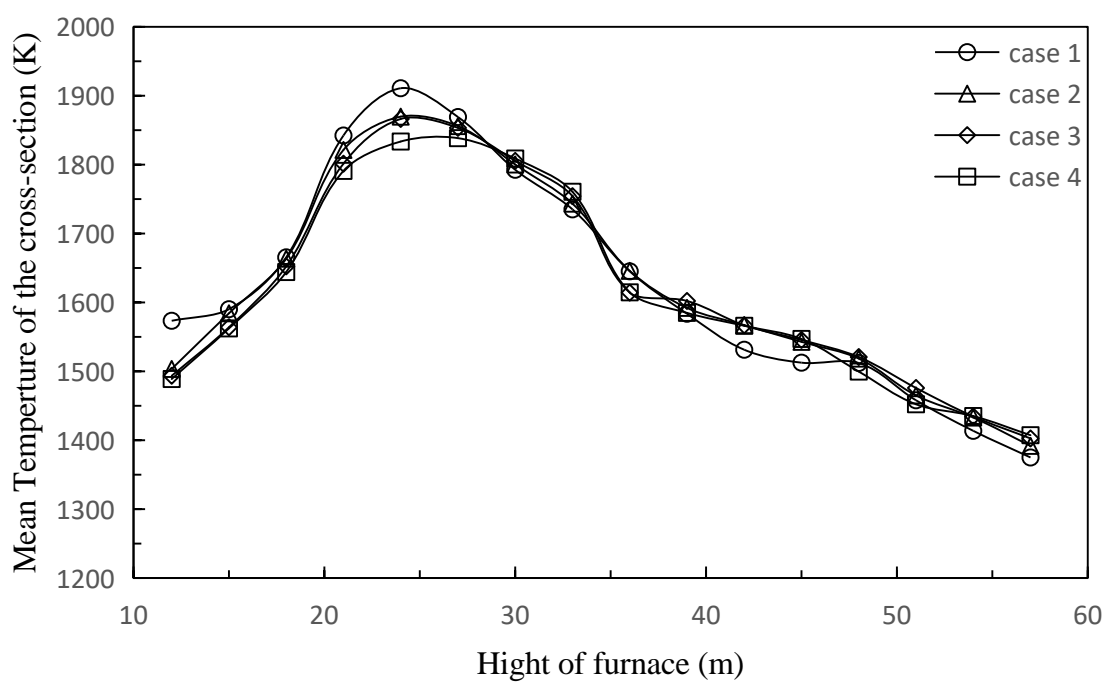

Figure 2. Mean temperature distribution of horizontal cross-section (K). 


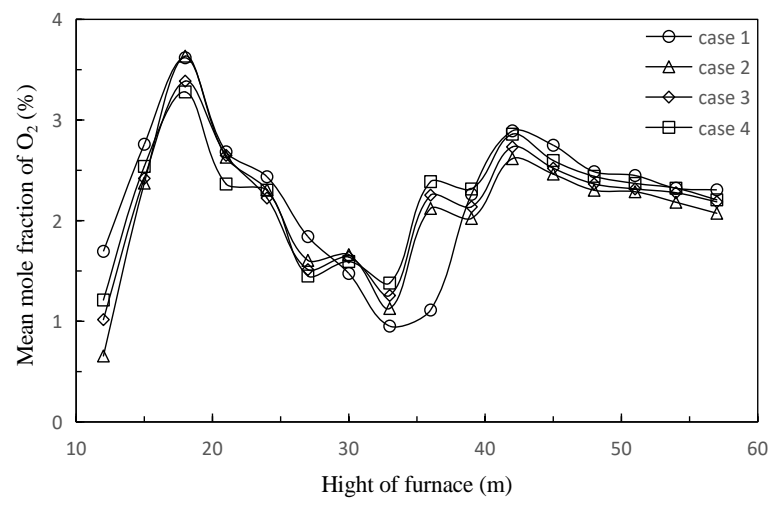

(a)

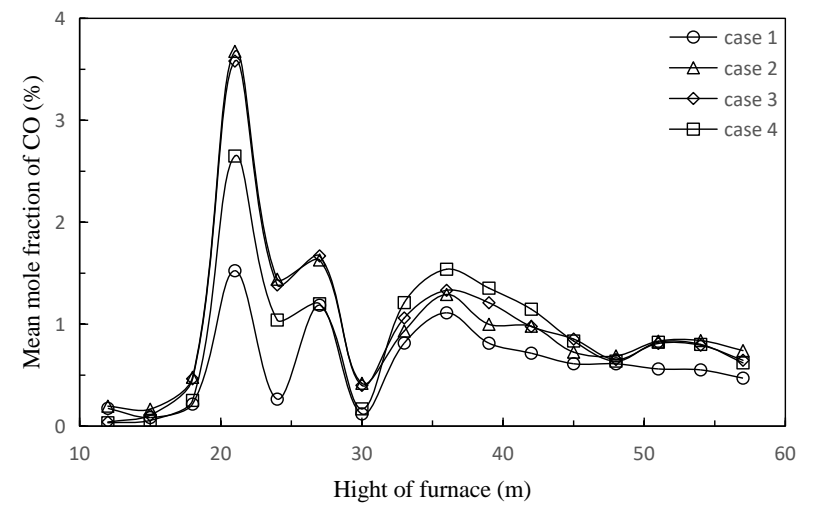

(b)

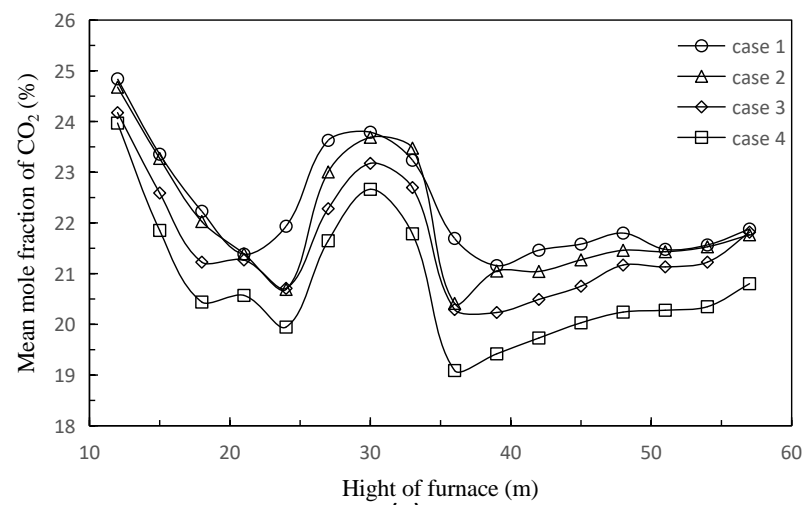

(c)

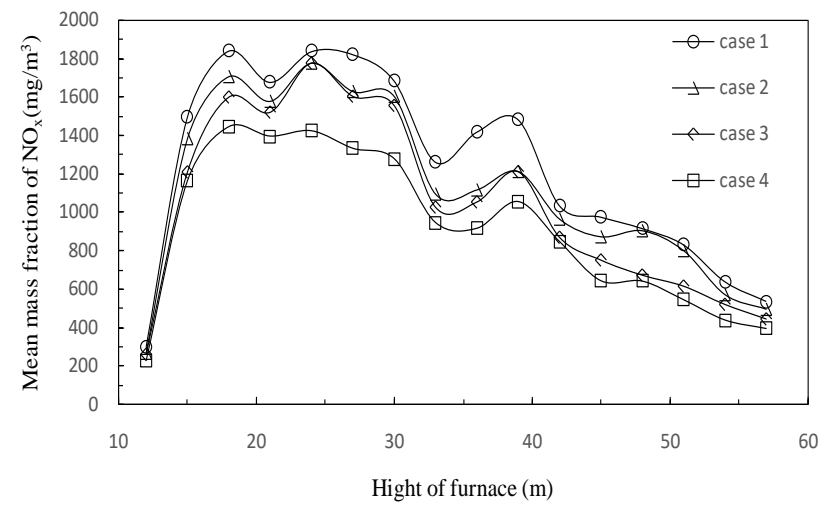

(d)

Figure 3. Volume fractions of $\mathrm{O}_{2}, \mathrm{CO}, \mathrm{CO}_{2}$ and $\mathrm{NOx}$ mass concentration. 
is higher than that of case $2-4$, but lower at the re-combustion zone. The $\mathrm{CO}$ and $\mathrm{CO}_{2}$ volume fraction have an inverse trend, being related to the concentration of $\mathrm{O}_{2}$. When $\mathrm{O}_{2}$ in flue gas decreases, $\mathrm{CO}$ increases, but $\mathrm{CO}_{2}$ decreases. This indicates that the simulation is reasonable. At the re-combustion area, the NO concentration decreases with the rise of $\mathrm{CH}_{4}$ volume fraction, in that a part of $\mathrm{NO}$ react with $\mathrm{CO}$ to generate $\mathrm{N}_{2}$ and $\mathrm{CO}_{2}$. At the re-combustion area, the $\mathrm{NOx}$ production decreases greatly with the rise of $\mathrm{CH}_{4}$ re-combustion ratio. Therefore, the productions of NOx at cases 2 - 4 are less than that at case 1 . The mean mass concentrations of NOx at furnace outlet are $535.05 \mathrm{mg} / \mathrm{m}^{3}, 497.48 \mathrm{mg} / \mathrm{m}^{3}$, $446.16 \mathrm{mg} / \mathrm{m}^{3}, 398.00 \mathrm{mg} / \mathrm{m}^{3}$ respectively, where the NOx emissions decrease by $7.02 \%, 16.61 \%$ and $25.61 \%$, respectively.

\section{Conclusions}

In this work, the numerical models are built to study the influence of different methane re-combustion ratio on the combustion process and the concentration distributions of the flue gas components in a retrofitted coal-fired boiler. The research work shows that methane gas re-combustion can lead to the temperature at primary zone decrease, reducing NOx formation in furnace. The re-combustion of methane gas can produce reduction atmosphere to further reduce $\mathrm{NO}$ to $\mathrm{N}_{2}$. The NOx concentration at the furnace outlet can be reduced by $7.02 \%, 16.61 \%$ and $25.61 \%$ respectively compared to strict coal combustion condition.

In order to ensure safe operation of boiler and effective reduction of NOx emissions from boiler, it is more reasonable to construct a re-combustion zone with $12.5 \%$ methane as re-combustion fuel. It is feasible to retrofit the old units in service to reduce NOx emission according to fuel staging combustion technology.

\section{Conflicts of Interest}

The authors declare no conflicts of interest regarding the publication of this paper.

\section{References}

[1] Wang, L.K., Pereira, N.C. and Hung, Y.T. (2004) Air Pollution Control Engineering: Handbook of Environmental Engineering. Vol. 1. Humana Press Inc., Totowa.

[2] Martin, M., Robert, D., Julian, W. and Andreas, H. (2017) Boiler Design with Solid-Gaseous Fuel Staging to Reduce $\mathrm{NO}_{x}$ Emissions and Optimize Load Flexibility. Chemical Engineering and Technology, 40, 289-297. https://doi.org/10.1002/ceat.201600199

[3] Kuang, M., Zhu, Q.Y., Li, Z.Q. and Zhang, X. (2013) Numerical Investigation on Combustion and $\mathrm{NO}_{x}$ Emissions of a Down-Fired 350 MWe Utility Boiler with Multiple Injection and Multiple Staging: Effect of the Air Stoichiometric Ratio in the Primary Combustion Zone. Fuel Processing Technology, 109, 32-42. https://doi.org/10.1016/j.fuproc.2012.09.035

[4] Zhou, H.H., Zhang, Z.D., Shao, W.W. and Xiao, Y.H. (2018) Analysis on $\mathrm{NO}_{x}$ 
Emission Characteristics of Natural Gas Fuel-Staged Combustion $\left(\mathrm{NO}_{x}\right)$. Journal of Propulsion Technology, 39, 1024-1032.

[5] Liu, H.P. and Dong, J.X. (2007) Intermediate Experimental Study on Low-NO ${ }_{x}$ Combustion Technology for Ultrafine Pulverized Coal Re-Burning. Northeast Electric Power Technology, No. 4, 1-4.

[6] Yun, S. and Fan, Z. (2018) Catalytic Reduction of $\mathrm{NO}_{x}$ by Biomass-Derived Activated Carbon supported Metals. Chinese Journal of Chemical Engineering, 10, 2077-2083. https://doi.org/10.1016/j.cjche.2018.04.019

[7] Zhang, X.T., Li, K.Y., Zhang, C. and Wang, A.J. (2020) Performance Analysis of Biomass Gasification Coupled with a Coal-Fired Boiler System at Various Loads. Waste Management, 105, 84-91. https://doi.org/10.1016/j.wasman.2020.01.039

[8] Glarborg, P., Kristensen, P.G. and Dam-Johansen, K. (2000) Nitric Oxide Reduction by Non-Hydrocarbon Fuels. Implications for Re-Burning with Gasification Gases. Energy \& Fuels, 14, 828-838. https://doi.org/10.1021/ef990186r

[9] Shi, J.R. and Xu, Y.N. (2011) Three-Dimensional Numerical Simulation of Gas Re-Burning Mixing Characteristics of Coal-Fired Boilers. Boiler Technology, 42, $39-42+47$.

[10] Wu, X.Y. and Song, Q. (2015) Synergetic Effect of Biomass Volatiles on NO Reduction and the Influence of K/Na on It. Fuel, 158, 634-640. https://doi.org/10.1016/j.fuel.2015.06.029

[11] Su, S., Xiang, J. and Sun, L.S. (2009) Study on Re-Burning to Reduce $\mathrm{NO}_{x}$ Emissions and Pulverized Coal Burnout Characteristics. Journal of Engineering Thermo-Physics, 30, 1767-1770.

[12] Lu, H.K. and Yang, W.J. (2010) Experimental Study on the Effect of Sodium Carbonate on Advanced Re-Burning of Methane. Proceedings of the CSEE, 30, 50-55. 